\title{
Altered Antibody Isotype in Cystic Fibrosis: Impaired Natural Antibody Response to Polysaccharide Antigens ${ }^{1}$
}

\author{
RICHARD B. MOSS, YAO-PI HSU, PETER H. VAN EEDE, ALFRED M. VAN LEEUWEN, \\ NORMAN J. LEWISTON, AND GERDA DE LANGE \\ Ross Mosier Laboratory for Cystic Fibrosis Research, Children's Hospital-Stanford, Department of Pediatrics, \\ Stanford University Medical School, Palo Alto, CA 94304 and Department of Immunogenetics, Central \\ Laboratory of the Netherlands Red Cross Blood Transfusion Service, Amsterdam [P.H.V.E., A.M.V.L., G.D.L.]
}

\begin{abstract}
Patients with cystic fibrosis (CF) have impaired natural (preinfection) IgG2 antibody responses to Pseudomonas aeruginosa lipopolysaccharide. To investigate the basis for this defect, we measured natural IgG and IgGl-4 antibody levels to Haemophilus influenzae type b polyribophosphate (PRP) and tetanus toxoid by enzymelinked immunosorbent assay in 24 adult $C F$ patients and 20 normal controls. Immunoglobulin heavy- and light-chain allotypes were determined on 146 Caucasian $C F$ patients and 96 controls. The tetanus toxoid-specific IgG response was predominantly IgG1. CF and control subjects had similar IgG and IgG1 antibody levels. The PRP-specific IgG response was predominantly IgG2. In contrast to tetanus toxoid results, CF patients had lower geometric mean level of PRP-specific IgG compared to normal controls $(p=0.0036)$. ELISA results were confirmed by liquid-phase ${ }^{3} \mathrm{H}$-PRP-binding assay: $C F$ patients had a geometric mean serum antibody level of 395 versus $922 \mathrm{ng} /$ $\mathrm{ml}$ in controls $(p=0.0044)$. PRP-specific IgG2 levels were also depressed in $C F$ patients $(p=0.03)$. CF patients had a lower prevalence of the $\mathrm{A} 2 \mathrm{~m}(2)$ allotype than the local racially matched control sample $(p<0.025)$. Other allotype prevalences including $G \mathbf{2 m}(n)$ and $\mathrm{Km}(1)$ were similar. Impaired IgG2 antibody responses to microbial polysaccharide surface antigens in CF patients might predispose them to persistent endobronchial infection and lead to production of nonopsonizing isotype responses. The potential role of $\mathrm{A} 2 \mathrm{~m}(2)$, coded for in the $\mathrm{H}$ chain locus on chromosome 14, is unknown, but could be related to muCosal IgA2 antibody responses. (Pediatr Res 22: 708-713, 1987)
\end{abstract}

Abbreviations

CF, cystic fibrosis

ELISA, enzyme-linked immunosorbent assay

TT, tetanus toxoid

PRP, Haemophilus influenzae type b polyribophosphate PA, Pseudomonas aeruginosa

LPS, lipopolysaccharide

Gm, Am, Km, immunoglobulin $\mathrm{G}$ and A heavy chain, and $\kappa$ light chain, allotypes

Received March 23, 1987; accepted August 4, 1987.

Correspondence and reprints R. B. Moss, M.D., Children's Hospital-Stanford, 520 Sand Hill Road, Palo Alto, CA 94304.

Supported by grants from the Cystic Fibrosis Foundation and Cystic Fibrosis Research, Inc.

${ }^{1}$ Presented in part at the Amcrican Academy of Allergy \& Immunology, Washington, D.C., February 23, 1987, and the Society for Pediatric Research, Anaheim, CA, April 29, 1987.
HSA, human serum albumin

PBS, phosphate-buffered saline

NGS, normal goat serum

OPD, $o$-phenylenediamine

EU, ELISA units

Mab, monoclonal antibody

Chronic airways infection with PA occurs in more than $80 \%$ of patients with CF and is responsible for most morbidity and mortality seen in this disease. The unique anatomic and bacteriologic features of this infection strongly suggest a local immune deficiency. The most promising candidate for such an immune deficiency is PA-specific nonopsonizing or blocking antibody detected in PA-infected CF patients $(1,2)$, since opsonic IgG antibodies specific for PA surface antigens such as LPS are essential for normal pulmonary and systemic phagocytic clearance $(3,4)$.

Several mechanisms might underlie the production of blocking antibodies to PA by CF patients. Proteolytic degradation of IgG into dysfunctional fragments has been demonstrated in vivo in CF bronchial lavage fluids and in vitro upon incubation with PA-derived elastase $(5,6)$. Changes in Fc-mediated effector function secondary to altered glycosylation of $\mathrm{CF}$ immunoglobulin could conceivably play a role (7). However, neither of these explanations account for the antigenic restriction of the opsonic defect to PA. In contrast, a change in the pattern (isotype distribution) of the antibody response subsequent to initial colonization might result in production of blocking antibody, an alteration capable of causing an antigen-specific immune deficiency $(8-10)$.

In studying this phenomenon, we were struck by the unexpected finding that patients with $\mathrm{CF}$ who were not infected with PA appeared to have an impaired humoral immune response to PA LPS, as manifested by subnormal levels of PA LPS-specific $\operatorname{IgG} 2$ antibodies and an apparent redistribution of the response to nonopsonizing IgG4 (8).

The adult human antibody response to polysaccharide antigens is normally at least partly restricted to the $\operatorname{IgG} 2$ subclass (1116). It seems possible that an inability to respond with an adequate $\operatorname{IgG} 2$ response could predispose to infection with polysaccharide-encapsulated pathogens such as PA. Herein, we explored the hypothesis that $\mathrm{CF}$ patients have a deficient response to polysaccharide antigens by measuring natural $\operatorname{IgG}$ and $\operatorname{IgG} 1$ 4 subclass antibody levels to PRP, and a control protein antigen, TT, in older patients with CF compared to normal subjects. We also examined allotypic markers on $\mathrm{CF}$ immunoglobulin to 08 


\section{MI:THODS}

Serum samples. Serum samples for antibody analysis were obtained from 24 older patients with ( $\mathrm{F}:(14$ males, 10 females. median age 24, range 16-37) attending the Stanford CF (enter clinic. All study subjects were $>16$ yr of age to control for ontogenetic variations in immune responses. Sixteen (F) patients had chronic endobronchial $P \wedge$ infection, as defined by $\geq 3$ positive sputum cultures of $\geq 1$ yr duration plus an abnormally high humoral immune response to $P \wedge I . P S$ (17). Fight $C F$ patients not infected with $P \wedge$ were also studied: these patients' sputum cultures grew a variety of other pathogenic bacteria. including staphlococeus aureus, nontypable llacmophilus influenacas or Haemophilus parainfluenzac', and various species of Enterobacteriaceac.

Ifacmophilus influenzac type b was not consistently cultured from the sputum of any of the study patients. One of the CF subjects' sputum culture grew this organism at the time of blood sampling, but approximately $25 \%$ had a history of intermittenty positive cultures in the past. The control group consisted of 20 healthy adult hospital workers (nine males. 11 females. median age $301 \frac{1}{2}$ yr, range $25-50 \mathrm{yr}$ ) involved in the care of ( $\mathrm{F}$ patients. None of the study subjects had received the Haemophilus type b PRP vaccine or a tetanus booster immunization within the preceding $10 \mathrm{yr}$.

Activation and coupling of PRP. Approximately $90 \mu \mathrm{g}$ lyophilized PRP (IIIB-Immune. Lederle. Pearl River. VY) were dissolved in $100 \mu 1$ distilled water and alkalinized by addition of

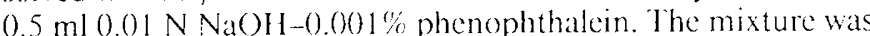
transferred to a glass tube containing $0.5 \mathrm{mg}$ cyanuric chloride for activation. Then $0.1 \mathrm{ml} 0.1 \%$ polylysine was added (18). Coupled antigen was diluted in normal saline to a final concentration of $1 \mu \mathrm{g} / \mathrm{ml}$ for solid phase adsorption.

EIIISA for PRI'-specific Ig(i. Assays were performed in 96 well flat-bottom polyvinylchloride microtiter plates (Dynatech. Alexandria, VA). Wells were coated with coupled PRP by incubation of 1()()$\mu \mathrm{l} /$ well overnight at $4^{\circ}$ (C. Following aspiration. open well sites were blocked by incubation with $200 \mathrm{\mu l} / \mathrm{well}(0.1 \%$ HSA-PBS-(0.01\% thimerosal for $1 \mathrm{~h}$ at $37^{\circ} \mathrm{C}$. Following aspiration and three washes with PBS-(0.05\% Tween-thimerosal. human test sera diluted $1 / 10$ and $1 / 100$ in $10 \%$ NGS-PBS-thimerosal diluent were added to wells in duplicate and incubated for $3 \mathrm{~h}$ at $4^{\circ} \mathrm{C}$. After aspiration and washing, monospecific affinity-

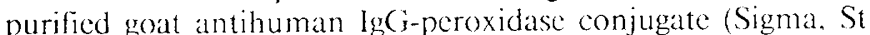
Louis, MO) $1 / 10(0)$ in $10 \%$ NCiS was added and incubated for $1 \mathrm{~h}$ at $37^{\circ} \mathrm{C}$. Following the final aspiration and washing. enzyme substrate (OPI) was added and incubated for $10-20$ min at $22^{\circ}$ $C$. The reaction was stopped with sulfuric acid and the resultant absorbance recorded at $490 \mathrm{~nm}$ using an automated microplate spectrophotometer.

The assay was standardized with a reference antiserum containing high-titer $/ 1$. influenzac type b antibodies quantified for all precipitating isotypes ( $\mathrm{S}$. Klein. US Standard human anti- $H$. influenzac type b capsular polysaccharide antibody. Iot 1983. Office of Biologics, FI)A, Bethesda. MID) (19). Net absorbances were derived by subtracting the higher of background readings obtained either by incubation of serum in paired wells without antigen or antigen-coated wells incubated with filler instead of serum. Background readings obtained from PRP-polylysine exposed to secondary antibodies were in the $0.05-(0.1$ (O) $492 \mathrm{~nm}$ range. Results. expressed in arbitrary I:U, were determined by interpolation of test sera net absorbance values to the standard curve.

LILISA for PRI' sperific-Ig(jl-4. The $\lg (; \mathrm{I} I$ ISA was modified by the use of murine Mabs specific for individual human $\lg (i 1$ 4 subclasses. Results for each subclass antibody assay were rendered comparable by adjusting dilutions of each antiisotypic Mab employed to vield identical net absorbance in binding to solid-phase adsorbed homologous purified human $\lg G$ subclass myelomas, as described elscwhere in detail (20). This assay provides semiquantitative estimates of the relative quantity and distribution of various $\lg (\mathrm{s}$ subclass antibodies for a given antigen. provided that these antibodies have similar affinities for that antigen.

Equivalent signal output (net absorbance) for human $\lg (i 1-4$ subclass-specific Mabs was established just prior to testing of serum samples for PRP IgG1-4 antibody levels. The equivalent dilutions and Mabs employed were as follows: $1 / 50(0)$ for Mab 912 anti-Ig(Y1 (Hybritech. I. a Jolla. (A): 1/300) for Mab (iO)M1 anti- $\operatorname{Ig}(\mathrm{S} 2$ (Seward. Birmingham. England): 1/20.0)(0) for Mab) 211 anti-IgC3 (Bethesda Research I aboratories. (iathersburg. MD): and 1/16,00) for Mab SK-44 anti-lgG4 (Bio-Yeda. Rehovot. Isracl). Antibodies were diluted in 10\%: V(iS. Mabs binding to homologous myelomas demonstrated parallel titration slopes with that of the reference serum binding to PRP.

Following serial incubation of PRP. HSA. and test sera diluted $1 / 2$ and $1 / 4$ for $5 \mathrm{~h}$ at $4^{\circ} \mathrm{C}$. Mabs were added and incubated overnight at $4 \mathrm{C}$. After aspiration and washing affinity-purified goat antimouse IgG-peroxidase conjugate (Bochringer Mannheim. Indianapolis. IN) $1 / 1000$ in $10 \%$ NGS was added and incubated $1 \mathrm{~h}$ at $37^{\circ} \mathrm{C}$. The reaction was then developed with OPD as described above. Results were standardized with the reference serum and expressed in arbitrary $\mathrm{EU}$

As with the $\operatorname{Ig} G$ FiLISA. negative controls included wells exposed to filler and serum. or antigen and filler. Nonspecilic binding was generally in the $0.1-(0.2$ (OI)49? $\mathrm{nm}$ range. In addition. unfractionated human serum containing no detectable antibody to $P R P(<15 \mathrm{ng} / \mathrm{ml}$ by radioactive antigen-binding assay: total $\lg (\mathrm{f}$ level $550 \mathrm{mg} / \mathrm{dl}$ ) was also studied at the same dilutions and found not to result in higher nonspecific binding levels than the other negative controls. The apparent insensitivity of the PRP Ig( 2 2 subclass FI.ISA resulted from the employ ment of the secondary antibody (GOM-1 at its antiisotypic "equivalent" dilution of $1 / 3()(0)$ (vide supra) (20). This was demonstrated in experiments showing PRP antibody-positive serum titration curves yielding net absorbances well over three times negative controls at dilutions of $\geq 1 / 32$ if GOM-1 was cmplored at dilutions of $1 / 500$ or $1 / 1000$ (data not shown). Similar net absorbance specific:nonspecific binding ratios were generated at the final $1 / 4$ serum screening and $1 / 3000)$ (FOM-1 dilutions employed.

Radinactive antigen-trinding assal: Total precipitating antibody to PRP was measured by a radioactive antigen binding assay using tritium-kabeled PRP as described (21). Freshly prepared $3^{\mathrm{H}}$-PRP (310 $\mathrm{n}(\mathrm{Ci} / 180 \mathrm{ng} / \mathrm{ml})$ was generously provided hy Đr. Porter Anderson. University of Rochester Medical center. Rochester, NY.

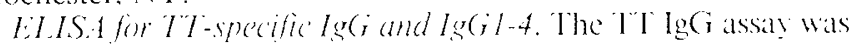
performed as described above for PRP. with the following exceptions: 1) T' $T^{-}$(Connaught. Swiftwater, PA) was directly adsorbed to wells by incubation for $1 \mathrm{~h}$ at $37^{\circ} \mathrm{C}$. The $\mathrm{I}^{\prime} \mathrm{T}$ antigen contained $8 \mathrm{If} \mathrm{U} / \mathrm{ml}$ and $26.5 \mu \mathrm{g} / \mathrm{ml}$ protein by the Folin phenol method. For adsorption, a protein concentration of $1 \mu \mathrm{g} / \mathrm{m} /$ was used. 2) Test sera were diluted $1 / 200$ and $1 / 1000$. 3) The assay was standardized by a reference curve of a human tetanus immune globulin preparation (Hyper-Tet. Cutter. Berkeley, (CA) containing 250 antitoxin $\mathrm{U} / \mathrm{ml}$. Results are given in arbitrary $\mathrm{E}$ ( derived from interpolation of test sera to the standard curve.

The $\mathrm{T} T \mathrm{Ig}(\mathrm{g} \mid-4$ subclass assay was performed as described for PRP. exeept that serum dilutions of $1 / 50$ and $1 / 200$ were used As for the Tl $\lg G$ assay. results were standardied using HyperTet and are also given in arbitrary EU. Isotype and antibody dilution curves were parallel. as were $\lg (\mathrm{il}$ (the major isotype) and $\lg (\mathrm{j}$ antibody curves.

Immunoglohulin allotyes. These were determined by hemagglutination inhibition in the laboratory of $(3$. de lange. The following allotypes were identified: Glm (\% a. $x, 1)$. (i2m (n). ( $33 \mathrm{~m}(\mathrm{~g} 1 . \mathrm{g} 5 . \mathrm{b} 1 . \mathrm{b} 5 . \mathrm{s} .1 . \mathrm{c} 3 .(5) . \mathrm{A} 2 \mathrm{~m}(1.2)$, and $\mathrm{Km}(1.3)$. In certain sera, further markers (bo, b3. b4) were lested. Sera were screened for anti- $\mathrm{im}$ and anti-Km antibodies. 
Statistical analysis. Geometric mean antibody levels were compared by the Mann-Whitney U test after logarithmic transformation, using two-tailed $p$ values for significance. Results were also analyzed using two-tailed Student's $t$ test on log transformed antibody values, but the nonparametric test results are reported due to non-Gaussian distribution histograms of some of the data. Parametric and nonparametric significance values were in close agreement and in no case were discordant conclusions reached by the two methods. Allotype prevalences were compared by the $\chi^{2}$ statistic with Yates' correction of continuity. Statistical calculations were performed using Statview 512 statistical software package (BrainPower, Inc., Calabasas, CA).

\section{RESULTS}

Patients with CF had similar TT IgG antibody levels to controls (Fig. 1A). The geometric mean value for the CF group was 8075 versus $6883 \mathrm{EU}$ in the control group $(p>0.2)$. Sixteen $\mathrm{CF}$ patients who were chronically infected with PA had similar TT antibody levels to eight $\mathrm{CF}$ patients without PA infection (geometric mean $=8390$ versus $6353 \mathrm{EU}, p=0.13$ ).

The IgG subclass antibody response to $\mathrm{TT}$ in healthy adults was predominantly $\operatorname{lgG} 1$, with minor contributions from $\operatorname{lgG} 2-$ 4. The hyperimmune standard globulin preparation used to standardize the ELISA contained the following distribution of $\operatorname{IgG}$ subclass TT antibodies, as determined in three separate experiments: $52-58 \% \operatorname{IgG} 1,15-17 \%$ IgG2, 12-14\% IgG3, and $15-17 \% \operatorname{IgG} 4$. CF patients demonstrated a similar distribution of humoral response to $\mathrm{TT}$, with $\mathrm{IgG} 1$ predominance. $\mathrm{TT}$ IgG and IgGI antibody levels showed a high degree of correlation for all subjects $(r=+0.87, p<0.001)$.

Individual serum IgG1 antibody levels to TT are shown in Figure $1 B$. The geometric mean TT IgGl antibody levels were similar in the patients with CF compared to normal controls (327 versus $398 \mathrm{EU}$, respectively). CF patients infected with $\mathrm{PA}$ and $\mathrm{CF}$ patients without PA infection had similar levels of TT IgGl (402 versus $218 \mathrm{EU}, p=0.14$ ).

The PRP-specific IgG antibody levels determined by ELISA are shown in Figure $2 A$. Unlike the results seen with TT, CF patients as a group had significantly lower serum IgG antibody

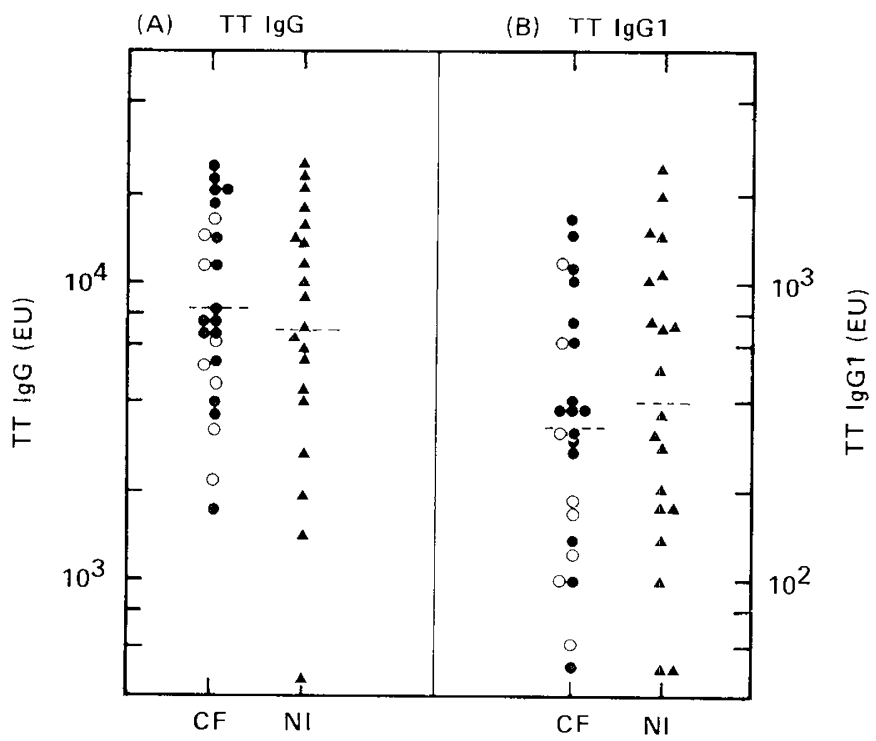

Fig. 1. A, scrum TT-specific IgG antibody levels in $\mathrm{CF}$ patients (circles) and controls (triangles); CF patients chronically infected with PA are indicated by closed circles. Geometric mean antibody levels were similar in the two groups. $B$, TT-specific IgG1 antibody levels in CF patients and controls. Geometric means were similar in the two groups. NI, controls.

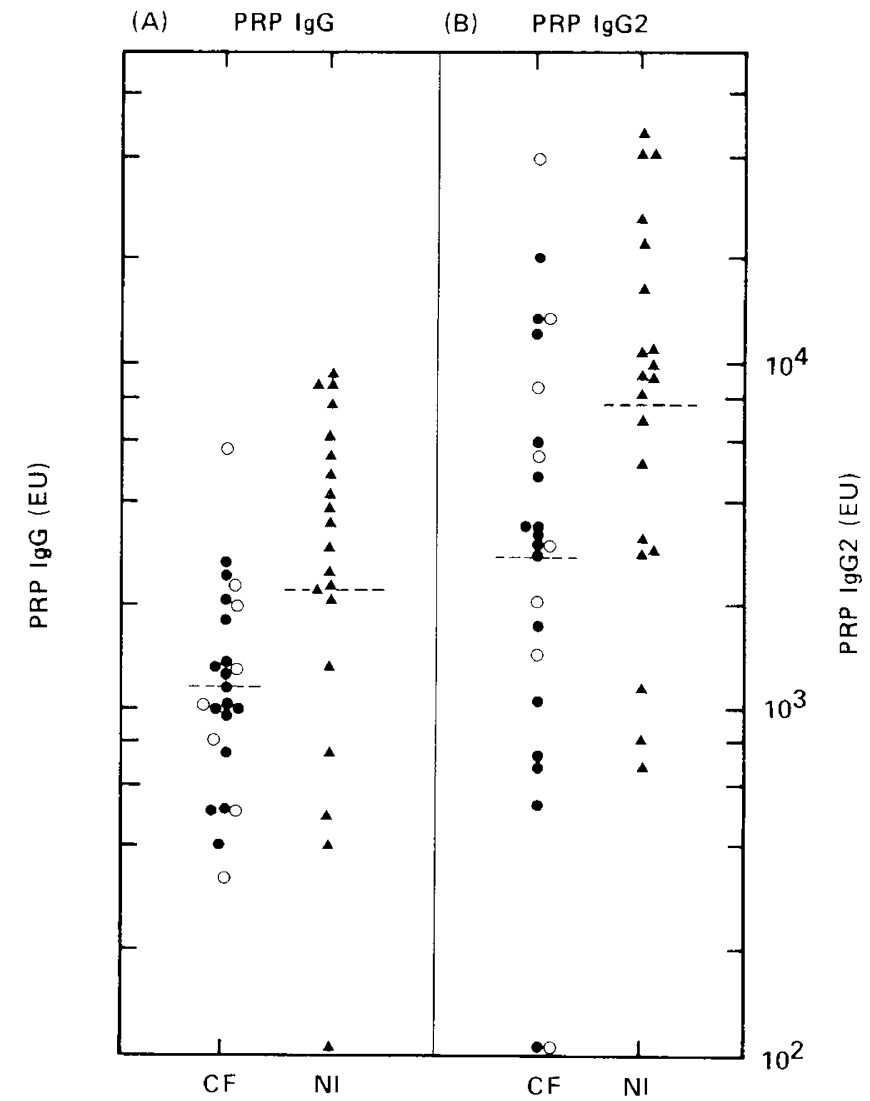

Fig. 2. $A$, serum PRP-specific IgG antibody levels in CF patients (circles) and controls (triangles); CF patients chronically infected with PA are indicated by closed circles. The geometric mean was lower in CF patients $(p=0.0036)$. $B$, serum PRP-specific IgG2 antibody levels in CF patients and controls. The geometric mean was lower in CF patients $(p$ $=0.03$ ).

levels to PRP compared to normal subjects. This occurred despite the fact that one control subject had a PRP IgG level below the detection limit of the standard curve $(30 \mathrm{ng} / \mathrm{ml})$. The geometric mean IgG PRP antibody level in patients with CF was 1140 versus $2310 \mathrm{EU}$ in controls $(p=0.0036)$. CF patients infected with PA and CF patients without PA infection had similar PRP $\mathrm{IgG}$ antibody levels (geometric mean $=1110$ versus 1200 ).

To further examine the response to PRP, a radioantigenbinding assay detecting antibodies of all isotypes binding to ${ }^{3} \mathrm{H}$ PRP and precipitable by $12.5 \%$ polyethylene glycol was used (21). In this assay, CF patients also demonstrated a significantly lower response (Table 1). The geometric mean antibody level in CF patient group was 395 versus $922 \mathrm{ng} / \mathrm{ml}$ in the control group $(p=0.0044)$. The results of the ${ }^{3} \mathrm{H}-\mathrm{PRP}$ radioantigen-binding assay and the PRP IgG ELISA correlated well $(r=+0.65, p<$ 0.001 ). The control subject who had the lowest level of PRPspecific IgG by ELISA (see above) had $88 \mathrm{ng} / \mathrm{ml}^{3} \mathrm{H}$-PRP binding antibody in the radioantigen assay. Six patients with CF $(25 \%)$ and two controls $(10 \%)$ had ${ }^{3} \mathrm{H}-\mathrm{PRP}$ binding levels $<150 \mathrm{ng} / \mathrm{ml}$.

The normal adult IgG antibody response to PRP was predominantly $\mathrm{IgG} 2$, although a variable minority contribution from IgG1 was apparent in some individuals in IgG1-4 subclass ELISA using equivalent signal-generating dilutions of subclass-specific secondary monoclonal antibodies (Fig. 3). The distribution of $\operatorname{IgG}$ subclasses in the reference serum was determined in three experiments to be approximately $28-31 \% \operatorname{IgG} 1,51-52 \% \operatorname{IgG} 2$, $10-13 \% \mathrm{IgG} 3$, and $7-8 \% \mathrm{IgG} 4$. The distribution of $\mathrm{CF}$ patient IgG subclass antibody response to PRP appeared similar to healthy controls. In particular, there was no clear-cut evidence of compensatory shifts in IgG subclass antibody response toward 
$\lg G 1,3$, or 4 (Fig. 3). PRP $\lg (j$ and $\lg G 2$ antibody levels for all subjects were significantly correlated $(r=+0.74, p<0.0() 1)$.

$\Lambda$ sith PRP $\operatorname{IgG}$ antibodies in ELISA and ${ }^{3} \mathrm{H}-\mathrm{PRP}$ binding precipitating antibodies, PRP $\operatorname{Ig}(22$ antibody levels determined by subclass EIISA were lower in CF patients than in controls (Fig. $2 B$ ). Two patients with $(\mathrm{F}$ had PRP $\lg (\mathrm{i} 2$ antibody levels below the detection limit of the assay; these two patients sera had ${ }^{3} \mathrm{H}-\mathrm{PRP}$ binding levels of 144 and $400 \mathrm{ng} / \mathrm{ml}$ and PRP $\operatorname{IgG}$ levels of 400 and $330 \mathrm{ng} / \mathrm{ml}$, respectively. The geometric mean PRP IgG2 antibody level in the (F group was 2727 versus 7526 $\mathrm{FU}$ in the control group $(\rho=0.029)$. CF patients infected with $P A$ and those without $P \wedge$ infection had similar levels of PRP $\operatorname{IgG} 2$ antibodies (geometric mean $=2425$ versus 3450 EU. $D=$ $0.3)$.

Immunoglobulin allotype determinations were done on serum samples from the 44 subjects assayed for antibody responses plus an additional 122 ( $\mathrm{F}$ and 76 controls. All subjects were more than 6 months of age. Control group sera were obtained from subjects with other respiratory diseases (mostly asthma) followed in the Stanford Pediatric Pulmonary clinic. Hispanic, black. and Oriental subjects were excluded from allotype data analysis.

Frequencies of all $\mathrm{Gm}, \mathrm{Km}$, and $\wedge 2 \mathrm{~m}(1)$ allotypes were not significantly different in the two groups. There was a possible trend toward lower frequency of $\mathrm{Km}(1)$ in the CF sample group $(14.3$ versus $21.1 \%, p>0.1)$. One ( $\mathrm{T}$ and one control subject were excluded from $\wedge 2 \mathrm{~m}$ analysis due to $\lg \wedge$ deficiency. $\wedge 2 \mathrm{~m}(2)$ was present in $4.1 \%$ of the CF group versus $13.8 \%$ of the control group $\left(x^{2}\right.$ with continuity correction $\left.=6.138 . p<0.025\right)$.

Anti-Km(1) antibody was present in 1 CF subject who was
$\mathrm{Km}(3+)$. Anti-Glm(a) antibodies were present in 1 (F: and 2 control subjects who were all $\mathrm{Gl} / \mathrm{m}(\mathrm{f}+)$. Finally, anti- $\mathrm{G} 3 \mathrm{~m}(\mathrm{~h}(\mathrm{)}) \mathrm{b} 1)$ was present in one CF subject who was (33m(g1, g5+).

\section{DISCUSSION}

The purpose of this study was to examine the natural antibody response of $\mathrm{CF}^{2}$ subjects to polvsaccharide and protein antigens in light of our previous finding of subnormal PA I.PS $\lg C$ ? antibody proportions and levels in $\mathrm{CF}$ patients not infected with PA (8). In a subsequent study, we noted a high correlation between PA I.PS IgG2 antibody levels and total serum $\lg \left(\mathrm{i}_{2}\right.$ protein levels. (F patients without $P A$ infection tended toward fow serum IgG2 levels, with two in 10) being $\lg (22$ deticient (22). One interpretation of these findings is that $\mathrm{CF}$ patients may have an impaired ability to mount a normal $\lg$ (32-restricted antibody response to polysaccharide antigens. To study this question, wo measured serum antibody levels to two ubiquitous antigens, the PRP capsular polvsaccharide of $I I$. influenzac $1 y p e$ b. and the protein antigen. $\mathrm{T} \Gamma$.

The systemic humoral immune response to various bacterial viral. dietary, and drug protein antigens. including I"I" and influenza vaccines has been extensively studied in patients with CF (23). These studies have uniformly suggested normal responses in CF patients. Our FIISA results for l" I-specitic IgC; confirm that adult ( $F$ patients have antibody levels to this antigen, due to universal childhood immunization, which are similar to controls.

The normal $\lg (\mathrm{j}$ antibody response to $\mathrm{I} / \mathrm{l}$ is predominantly

Table 1. Antibody response's to T\% and PRP in pationts with $(\%$ and controls

Group

\begin{tabular}{|c|c|c|c|c|c|}
\hline \multirow[b]{2}{*}{ Antibody (unit) } & \multicolumn{2}{|c|}{$C F(n=24)$} & \multicolumn{2}{|c|}{ Normal $(n=20)$} & \multirow[b]{2}{*}{$\begin{array}{c}l \\
\text { (2-tailed) }\end{array}$} \\
\hline & $\mathrm{GM}^{*}$ & $\begin{array}{c}\text { Mean } \\
\log _{10} \pm S \mathrm{SD}\end{array}$ & (jM & $\begin{array}{c}\text { Mean } \\
\log _{(11} \pm S D\end{array}$ & \\
\hline I"I'Ig(i (I:U) & 8075 & $3.91 \pm 0.33$ & 6883 & $3.84 \pm 0.45$ & $\therefore S$ \\
\hline TI Ig(il (I:U) & 327 & $2.52 \pm 0.43$ & 398 & $2.60 \pm 0.50$ & $\therefore S$ \\
\hline${ }^{3} \mathrm{H}$-PRP precipitating ( $\mathrm{ng} / \mathrm{ml}$ ) & 395 & $2.60 \pm 0.41$ & 922 & $2.97 \pm 0.45$ & $0.000 .4+4$ \\
\hline PRP Ig(i (I:U) & 1143 & $3.06 \pm 0.29$ & 231.3 & $3.36 \pm 0.60$ & 0.00 .36 \\
\hline$P R P \operatorname{Ig}(i 2(\mathrm{E}: \mathrm{U})$ & 2727 & $3.44 \pm 0.65$ & 7526 & $3.88 \pm 0.55$ & 0.0 .3 \\
\hline
\end{tabular}

* Geometric mean titer.

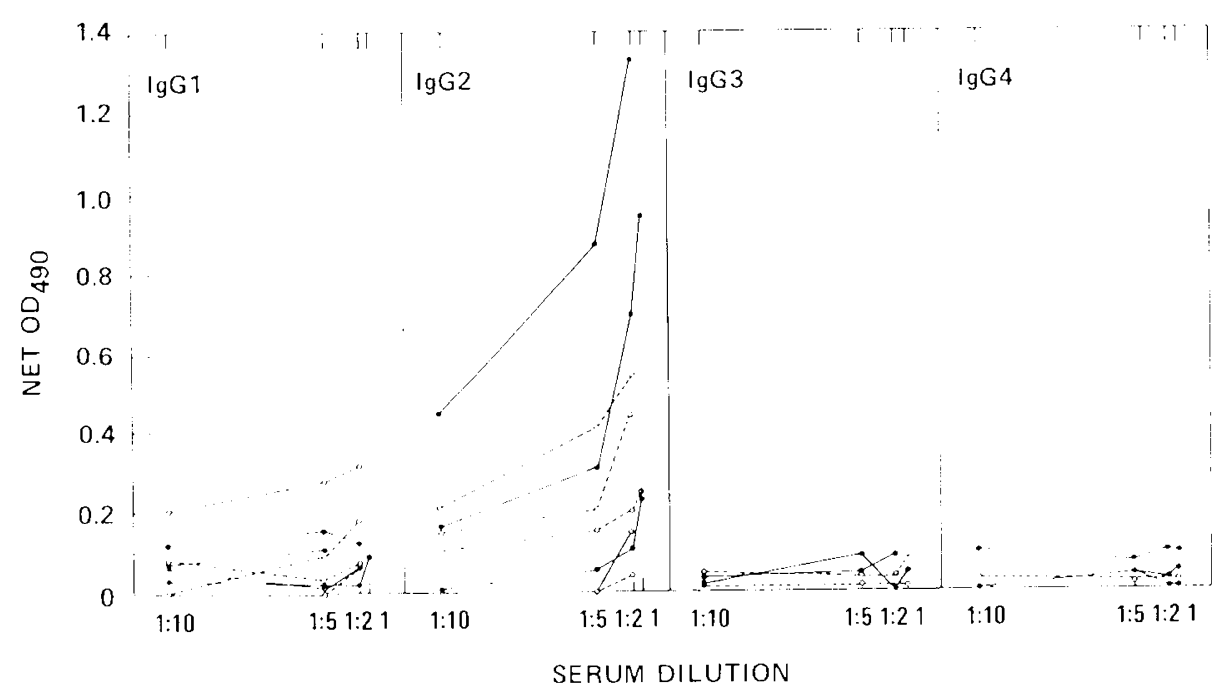

Fig. 3. PRP-specific Ig(il-4 serum antibody titration curves of (1: patients (deshed lines) and controls (.wolid lines). Vet absorbantece (O) 490$)$ have been equilibrated by the myeloma method to reflect approximate distribution of serum antibodies (see text). I.ow PRP-specifie Ig(i2 levels in CF patients are not compensated by increases in other isotype antibodies. 
IgG1 (24-27). Our data confirm these studies and indicate that patients with $\mathrm{CF}$ also respond to $\mathrm{TT}$ with a dominant $\mathrm{IgGl}$ response, which is quantitatively similar to that of controls. A variable minority contribution of IgG2-4 TT antibodies may be seen in individual subjects, with $\mathrm{lgG} 4$ being particularly important in some (25-27).

Examination of the antibody response to polysaccharide antigens highlights a number of qualitative and quantitative differences vis-à-vis the response to proteins. First, the isotype pattern of response is qualitatively distinct, with predominance of $\operatorname{IgG} 2$ antibodies $(11-16)$. Second, the ontogeny of response differs, with a later maturation of immune responsiveness, which for some antigens may extend well into the latter years of childhood $(28,29)$. To eliminate the ontogenetic factor, we restricted our investigation in this study to immunologically adult ( $>16 \mathrm{yr}$ old) subjects.

Antibodies to $H$. influenzae type b capsular PRP are present in virtually all unimmunized adults at levels sufficient to prevent invasive $H$. influenzae type b disease $(\geq 150 \mathrm{ng} / \mathrm{ml}$ precipitable antibody) (19). In contrast to immunization-induced TT antibodies, PRP antibodies are thought to be induced as a result of natural exposure to enteric microbial flora, especially Escherichia coli, which has a capsular polysaccharide antigen (K 100) which is cross-reactive with PRP (30).

The major finding of this study is that adult CF patients have significantly lower levels of serum PRP IgG antibodies than controls (Fig. 2). The normal human IgG antibody response to PRP is partly restricted to $\operatorname{IgG} 2$, with a variable minority contribution from IgG1 $(12,31)$. Recently, Weinberg et al. (32) demonstrated that $\mathrm{IgG} 2$ subclass PRP antibodies were functional in in vitro bactericidal and in vivo rat bacteremia protection assays. Similar data supporting a protective biologic role for polyclonal or monoclonal human IgG2 antibodies to other polysaccharides, such as type III group B Streptococcus capsule and Pseudomonas aeruginosa LPS, have been obtained (Masuho Y, personal communication) (33). Moreover, a number of recent clinical studies suggest that deficiency of $\mathrm{IgG} 2$ (or pathogen-specific IgG2 antibodies even when IgG2 levels are normal) may predispose to sinopulmonary infection $(34,35)$. CF patients in our study, as with the normal controls, made a predominantly $\operatorname{IgG} 2$ response, without evidence of a compensatory shift to $\operatorname{IgG} 1$ or other $\operatorname{IgG}$ isotypes. As with IgG antibodies, PRP-specific IgG2 levels were generally lower in CF patients. These findings, particularly in light of our previous observations regarding P. aeruginosa LPS antibodies (8), suggest IgG2 responses to polysaccharide antigens, of potential functional importance, might be impaired in $\mathrm{CF}$ patients.

The human response to PRP includes $\operatorname{IgM}$ and IgA antibodies, which we did not directly measure. However, we confirmed the lower PRP IgG antibody levels in CF patients determined by ELISA by radioantigen-binding assay (21), suggesting that compensatory or increased systemic $\operatorname{IgA}$ or $\operatorname{IgM}$ antibody responses do not occur to a major degree in these patients.

An alternative explanation for lower PRP antibody levels in $\mathrm{CF}$ patients is that antigenic exposure might somehow be less than that experienced by normal individuals. In particular, since natural PRP antibodies are thought to arise from responses to normal gut flora (especially $E$. coli) (30), could frequent antibiotic treatment deprive the CF individual of this antigenic stimulation? Available data on colonization rates and immune responses to enteric bacteria, including $E$. coli, in patients with $C F$ would appear to preclude this possibility, since these are both normal or increased in CF patients despite vigorous antibiotic treatment (36-39). Increased direct PRP antigenic stimulation in CF patients seems unlikely, however, given the fact that most $H$ influenzae respiratory tract colonization and infection in $\mathrm{CF}$ patients is due to nontypeable, acapsulate strains (40).

To investigate a possible genetic basis for this impairment, we examined allotypes of $\mathrm{CF}$ and control immunoglobulins. We found that the allotypic light chain marker $\mathrm{Km}(1)$, previously associated in certain populations with enhanced immune responsiveness to PRP and other polysaccharide antigens (41-45), had a lower prevalence in our CF sample population than controls. The exclusion of Hispanic individuals, however, eliminated the difference, rendering conclusions difficult. It thus seems possible that lower $\mathrm{IgG} 2$ responses may have a genetic component detectable by $\mathrm{Km}(1)$ allotype analysis. We did not find any differences in the prevalence of the $\operatorname{IgG} 2$ heavy chain allotype $\mathrm{G} 2 \mathrm{~m}(\mathrm{n})$, which Ambrosino et al. (45), but not Granoff et al. $(43,44)$, have correlated with PRP immune responsiveness.

Another allotype, found on IgA2 heavy chains, A2m(2) (46), was also less frequent in CF patients. $\mathrm{A} 2 \mathrm{~m}(2)$ is relatively rare in Caucasian populations and more common in blacks and Orientals (47). We excluded the latter racial groups from our analysis, and the presence or absence of Hispanic individuals did not alter the results. To our knowledge, no studies of IgA allotypes and immune responses have been published. It is intriguing to note, however, that IgA2 plays a prominent role in local mucosal IgA production (48). In particular, $\operatorname{IgA} 2$ antibodies appear to provide the major portion of the mucosal IgA antibody response to bacterial LPS and staphylococcal ribitol teichoic acid $(15,49)$. Aberrations in the secretory $\operatorname{IgA}$ system have been reported in CF patients, but no data on IgA subclass composition were presented (50). Pathology in $\operatorname{IgA}, \operatorname{IgG}$, or both isotypes could play a role in development of $\mathrm{CF}$ lung disease. Independent, complementary functions for secretory IgA and $\operatorname{IgG}$ subclass antibodies in pulmonary defense are currently postulated via prevention of mucosal microbial adherence and colonization by the former, and subsequent opsonophagocytosis if necessary by the latter (51).

In future studies it will be necessary to examine primary and anamnestic responses of $\mathrm{CF}$ patients to polysaccharide vaccines. It will also be useful to study fluctuations in bacterial polysaccharide-specific antibody levels over time in relation to respiratory tract colonization and episodes of infection. At present, the role of a rather restricted but potentially important immune response, impaired $\operatorname{IgG} 2$ antibody responses to polysaccharide antigens, in predisposing CF patients to chronic airway infection remains speculative. Continued study of host responses seems likely to provide additional clues to those lines of inquiry focused solely on bacterial virulence factors in understanding the uniquely circumscribed nature of pulmonary infection in $\mathrm{CF}$.

\section{REFERENCES}

1. Thomassen MJ, Boxerbaum B, Demko CA, Kuchenbrod PJ Dearborn DG Wood RE 1979 Inhibitory effect of cystic fibrosis serum on Pseudomonas phagocytosis by rabbit and human alveolar macrophages. Pediatr Res 13:1085-1088

2. Fick RB, Naegel GP, Matthay RA. Reynolds HY 1981 Cystic fibrosis Pseudomonas opsonins. Inhibitory nature in an in vitro phagocytic assay. $\mathrm{J}$ Clin Invest 68:899-914

3. Young LS, Armstrong D 1972 Human immunity to Pseudomonas aeruginosa. 1. In vitro interaction of bacteria, polymorphonuclear leukocytes, and serum factors. J Infect Dis 126:257-276

4. Reynolds HY, Kazmierowski JA, Newball HH 1975 Specificity of opsonic antibodies to enhance phagocytosis of Pseudomonas aeruginosa by alveolar macrophages. J Clin Invest 56:376-385

5. Fick RB, Naegel GP, Squier SU, Wood RE, Gee JBL, Reynolds HY 1984 Proteins of the cystic fibrosis respiratory tract. Fragmented immunoglobulin $G$ opsonic antibody causing defective opsonophagocytosis. J Clin Invest 74:236-248

6. Fick RB, Baltimore RS, Squier SU, Reynolds HY $1985 \mathrm{IgG}$ proteolytic activity of Pseudomonas aeruginosa in cystic fibrosis. J Infect Dis 51:589-598

7. Margolies R, Boat TF 1983 The carbohydrate content of IgG from patients with cystic fibrosis. Pediatr Res 17:931-935

8. Moss RB. Hsu YP, Sullivan MM, Lewiston NJ 1986 Altered antibody isotype in cystic fibrosis: possible role in opsonic deficiency. Pediatr Res 20:453-459

9. Fick RB Olchowski J, Squier SU, Merrill WW Reynolds HY 1986 Immunoglobulin G subclasses in cystic fibrosis. Am Rev Respir Dis 133:418-422

10. Shryock TR, Molle JS, Klinger JD, Thomassen MJ 1986 Associations with phagocytic inhibition of anti-Pseudomonas aeruginosa immunoglobulin $\mathrm{G}$ antibody subclass levels in serum from patients with cystic fibrosis. $\mathrm{J}$ Clin Microbiol 23:513-516

11. Yount WJ, Dorner MM, Kunkel HG, Kabat EA 1968 Studies on human antibodies. IV. Selective variations in subgroup composition and genetic markers. J Exp Med 127:633-646 


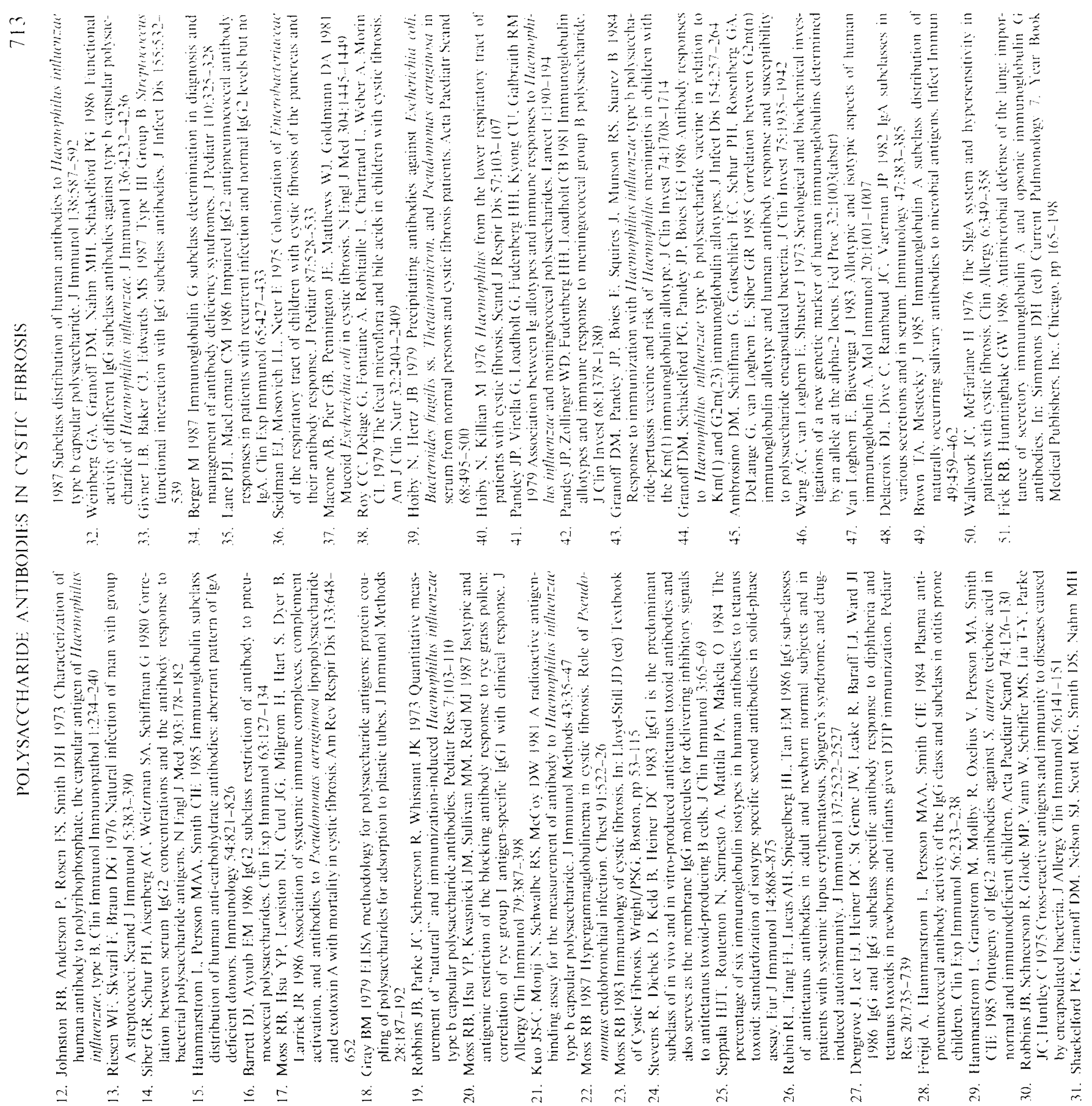

